\title{
Energy Performance of a Kalina Cycle based CHP plant driven by low-enthalpy geothermal sources
}

\author{
Gabriel Mocanu, Ion V. Ion ${ }^{1 *}$, and Florin Popescu ${ }^{1}$ \\ ${ }^{1}$ „Dunarea de Jos” University of Galati, 47 Domneasca St., 800008 Galati, Romania
}

\begin{abstract}
The low-enthalpy geothermal sources can be efficiently exploited for heat and power cogeneration by using the KCS-34 Kalina cycle systems. The maximum power for given heat source temperature and cooling temperature is obtained for a certain value of the ammonia-water solution concentration and turbine exit pressure. The Cycle-Tempo simulation software is a very useful tool to investigate variation of some cycle parameters in order to obtain the maximum energy efficiency. In this paper the performance of a KCS34 Kalina cycle based CHP plant is investigated to exploit a geothermal source with $120^{\circ} \mathrm{C}$ temperature present in North-West of Romania. It was found that by using the heat and power cogeneration the energy efficiency can be increased from $16.76 \%$ to $57.86 \%$ in winter and to $33.44 \%$ in summer.
\end{abstract}

\section{Introduction}

Geothermal energy is one of the renewable resources with the highest potential but also the least exploited source. It has been used to heat homes and public bathrooms since Roman times, and to produce electricity since 1904, when the first power plant was put into operation in Larderello, Italy. Europe has a huge potential for geothermal energy, especially low-enthalpy geothermal sources. Europe can produce (80-100) GWe by using the geothermal energy. Currently only $1.5 \mathrm{GW}$ of electricity is produced [1]. Romania has in the North-West of the country geothermal resources with temperatures between $70^{\circ} \mathrm{C}$ and $130^{\circ} \mathrm{C}$ at depths of 800 and $3500 \mathrm{~m}$. In Romania there are more than 10 Geothermal District Heating $(\mathrm{GeoDH})$ systems and one demonstration geothermal power plant of $50 \mathrm{kWe}$ working on Organic Rankine Cycle (ORC) which uses pentafluoropropane (HFC-245fa) as working fluid.

For the conversion of low-enthalpy geothermal energy $\left(<150^{\circ} \mathrm{C}\right)$ into electricity the only systems that can be used are the ORC and Kalina cycle systems. These two systems have been extensively studied for thermodynamic or thermoeconomic optimization [2-16]. Studies performed to date have concluded that for temperatures above $100^{\circ} \mathrm{C}$ of geothermal water the Kalina cycle is more efficient than the ORC and that the KCS-34 Kalina cycle system is best suited for geothermal brine temperatures below $121^{\circ} \mathrm{C}$ and for cogeneration of heat and power $[6,7]$.

Although the capital costs are higher for the Kalina cycle systems than for the ORC systems, they are offset by the ability to generate higher power with higher efficiencies of the Kalina cycle at the same temperature of the geothermal brine. This is possible due to the improved heat exchange from the geothermal brine [17].

In Romania there is, so far, a single reservoir (Bors reservoir) with a temperature higher than $130^{\circ} \mathrm{C}$ at an average depth of $2500 \mathrm{~m}$ and with wellhead temperature of $120^{\circ} \mathrm{C}$. In this reservoir there are 3 wells with a total artesian production of up to $30 \mathrm{l} / \mathrm{s}$. The currently flow rate could be increased to $30 \mathrm{l} / \mathrm{sec} /$ well by pumping [18-20].

The energy efficiency of current geothermal power plants is (11-15)\%. By simultaneous generation of heat and power, the overall energy efficiency can be increased to $(35-60) \%$. In the paper [18] a system operating on ORC is proposed to exploit the geothermal brine from Bors and to generate electricity and to raise the temperature of the cooling water from $(10-25)^{\circ} \mathrm{C}$ to $(60-80)^{\circ} \mathrm{C}$ to be used for feeding a district heating system. By using also, the residual heat contained in the geothermal brine discharged from the vapour generator (having a temperature of $80^{\circ} \mathrm{C}$ ), the overall energy efficiency of the system can reach $98 \%$.

As it is known, in temperate climate zones the demand for hot water for heating varies greatly from one season to another, only the demand for domestic hot water is almost constant all year round. For example, in Oradea, the load of the district heating system varies from $803930 \mathrm{MWh}$ in winter to $158720 \mathrm{MWh}$ in summer, a decrease of $80 \%$.

This paper analyses the performance of a system operating on the KCS-34 Kalina cycle that produces power and supplies a district heating system (with a supply and return temperature of $90^{\circ} \mathrm{C}$ and $60^{\circ} \mathrm{C}$, respectively) with variable demand of hot water for heating. The system uses as a primary energy source the geothermal brine with temperature of $120^{\circ} \mathrm{C}$ available in the Bors area (near Oradea city), Romania. To meet the variable hot water load of the district heating system, the water is heated in a series-parallel combination configuration. This configuration allows better utilization of the geothermal source.

\footnotetext{
*Corresponding author:ion.ion@ugal.ro
} 
As the mass fraction of ammonia entering the turbine and the turbine exit pressure have a great influence on the performance of the Kalina cycle [21] the optimal values of these parameters were searched.

\section{Modelling of the KCS34-Kalina cycle}

Based on the concept of the KCS-34 Kalina cycle, a combined heat and power (CHP) system driven by low-enthalpy geothermal resource as shown in Figures 1 and 2 was designed. The hot geothermal brine supplies the evaporator (7) and heat exchanger (15) giving off heat to ammonia-water mixture and district heating water, respectively. The ammoniawater mixture is separated into ammonia-rich vapour mixture and weak liquid mixture in the separator (8). The vapour of ammonia-rich mixture expands in turbine (1) generating electric power. The weak liquid mixture from separator passes through the high-temperature regenerator (6) heating the working fluid flowing to evaporator, and then is throttled in valve (9) to the turbine exit pressure and mixed with turbine exit working fluid in the mixer (2). The basic solution resulting from mixture (2) passes through the low-temperature regenerator (3) and is cooled in the condenser (4). The condensate is aspired by pump (5) and pumped to separator pressure (8) and heated in the low-temperature regenerator (3) and in high-temperature regenerator (6), and converted into liquid and vapour mixture in the evaporator (7). The splitter (13) has the role of regulating the flow rate of geothermal brine through the heat exchanger in accordance with the demand of district heating system. The cogeneration plant is designed to follow the heat demand.

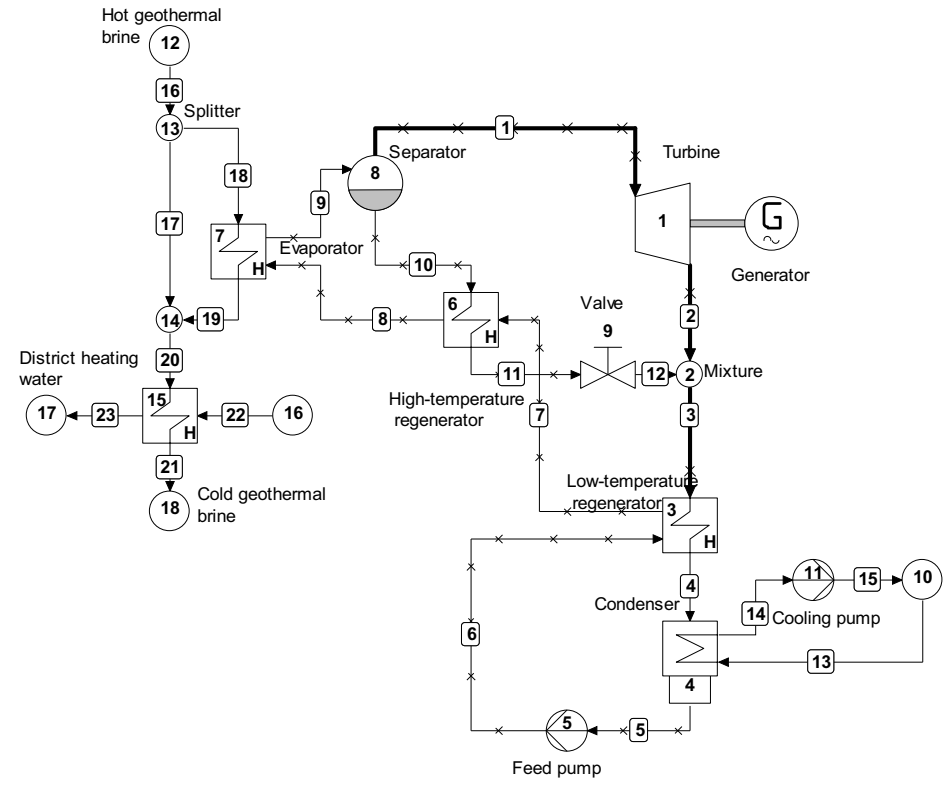

Fig. 1. Configuration of KCS-34 Kalina cycle based CHP plant.

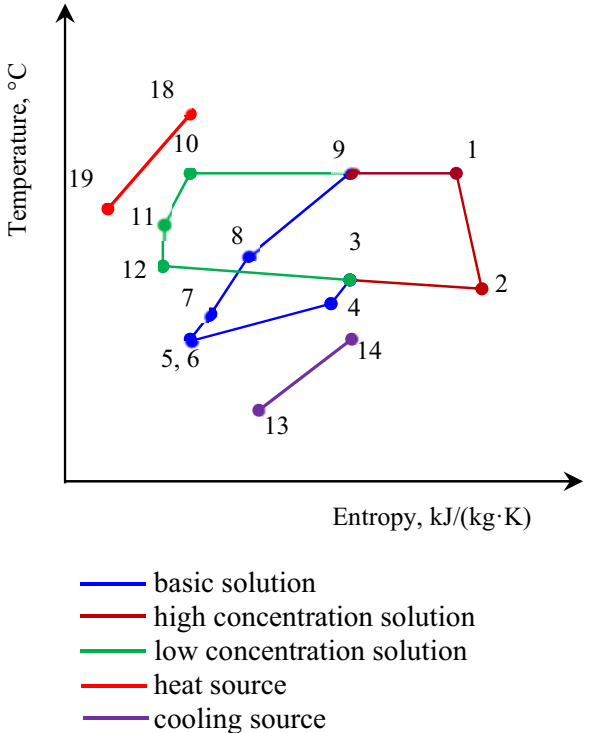

Fig. 2. T-s diagram of KCS-34 Kalina cycle.

To analyse the energy performance of the system, the following thermodynamic model was developed considering a steady-state operation.

Electric generator work output:

$$
W_{G}=\dot{m}_{1}\left(h_{1}-h_{2}\right) \eta_{T} \eta_{G}
$$

Feed pump work consumption:

$$
W_{F P}=\dot{m}_{5}\left(h_{6}-h_{5}\right) / \eta_{F P}
$$

Cooling pump work consumption:

$$
W_{C P}=\dot{m}_{c w}\left(h_{15}-h_{14}\right) / \eta_{C P}
$$

Cycle net power output:

$$
W_{\text {net }}=W_{G}-W_{F P}-W_{C P}
$$

Heat exchanged in evaporator:

$$
Q_{e v}=\dot{m}_{18}\left(h_{18}-h_{19}\right)=\dot{m}_{8}\left(h_{9}-h_{8}\right)
$$


Heat exchanged in low-temperature regenerator:

$$
Q_{\text {LTR }}=\dot{m}_{3}\left(h_{3}-h_{4}\right)=\dot{m}_{7}\left(h_{7}-h_{6}\right)
$$

Heat exchanged in high-temperature regenerator:

$$
Q_{H T R}=\dot{m}_{8}\left(h_{8}-h_{7}\right)=\dot{m}_{10}\left(h_{10}-h_{11}\right)
$$

Heat exchanged in condenser:

$$
Q_{C}=\dot{m}_{8}\left(h_{4}-h_{5}\right)=\dot{m}_{c w}\left(h_{14}-h_{13}\right)
$$

Mass and energy balance equations for separator:

$$
\begin{gathered}
\dot{m}_{9}=\dot{m}_{1}+\dot{m}_{10} \\
\dot{m}_{9} x_{9}=\dot{m}_{1} x_{1}+\dot{m}_{10} x_{10} \\
\dot{m}_{9} h_{9}=\dot{m}_{1} h_{1}+\dot{m}_{10} h_{10}
\end{gathered}
$$

Mass and energy balance equations for mixture 2:

$$
\begin{gathered}
\dot{m}_{2}=\dot{m}_{12}+\dot{m}_{3} \\
\dot{m}_{2} x_{2}=\dot{m}_{12} x_{12}+\dot{m}_{3} x_{3} \\
\dot{m}_{2} h_{2}=\dot{m}_{12} h_{12}+\dot{m}_{3} h_{3}
\end{gathered}
$$

Heat supplied to district heating system:

$$
Q_{D H S}=\dot{m}_{b t}\left(h_{20}-h_{21}\right)=\dot{m}_{D H}\left(h_{23}-h_{22}\right)
$$

Electrical efficiency of power system:

$$
\eta_{e l}=\frac{W_{n e t}}{Q_{e v}}
$$

Overall energy efficiency of the CHP system:

$$
\eta_{e l}=\frac{W_{n e t}+Q_{D H S}}{\dot{m}_{16}\left(h_{16}-h_{21}\right)}
$$

where: $\dot{m}$ is mass flow rate $(\mathrm{kg} / \mathrm{s}) ; x$ is ammonia mass fraction; $h$ is enthalpy $(\mathrm{kJ} / \mathrm{kg}) ; Q$ is heat flow rate $(\mathrm{kW}) ; W$ is power $(\mathrm{kW})$.

The KCS-34 Kalina cycle system model was built and thermodynamically investigated by using the Cycle-Tempo Release 5.1.6 software package. The simple KCS-34 Kalina cycle model was validated by simulation of the Kalina cycle geothermal power plant in Husavic, Iceland. The simulation results for the same input data are in good agreement with data from [13].

In order to optimize the KCS-34 Kalina cycle based cogeneration system, namely to obtain the maximum power output, it is necessary to find the optimal values for the mass fraction of ammonia-water working agent and the turbine exit pressure in accordance with the temperature of hot and cold sources. Following the tests of several values of the mass fraction in the range $0.6-0.85$, the value of 0.83 was found, for which the power generated by the turbine is maximum. From the temperature-concentration diagram of ammonia-water mixture at different pressures (Fig. 3) the turbine exit pressure of 10 bars was chosen. 


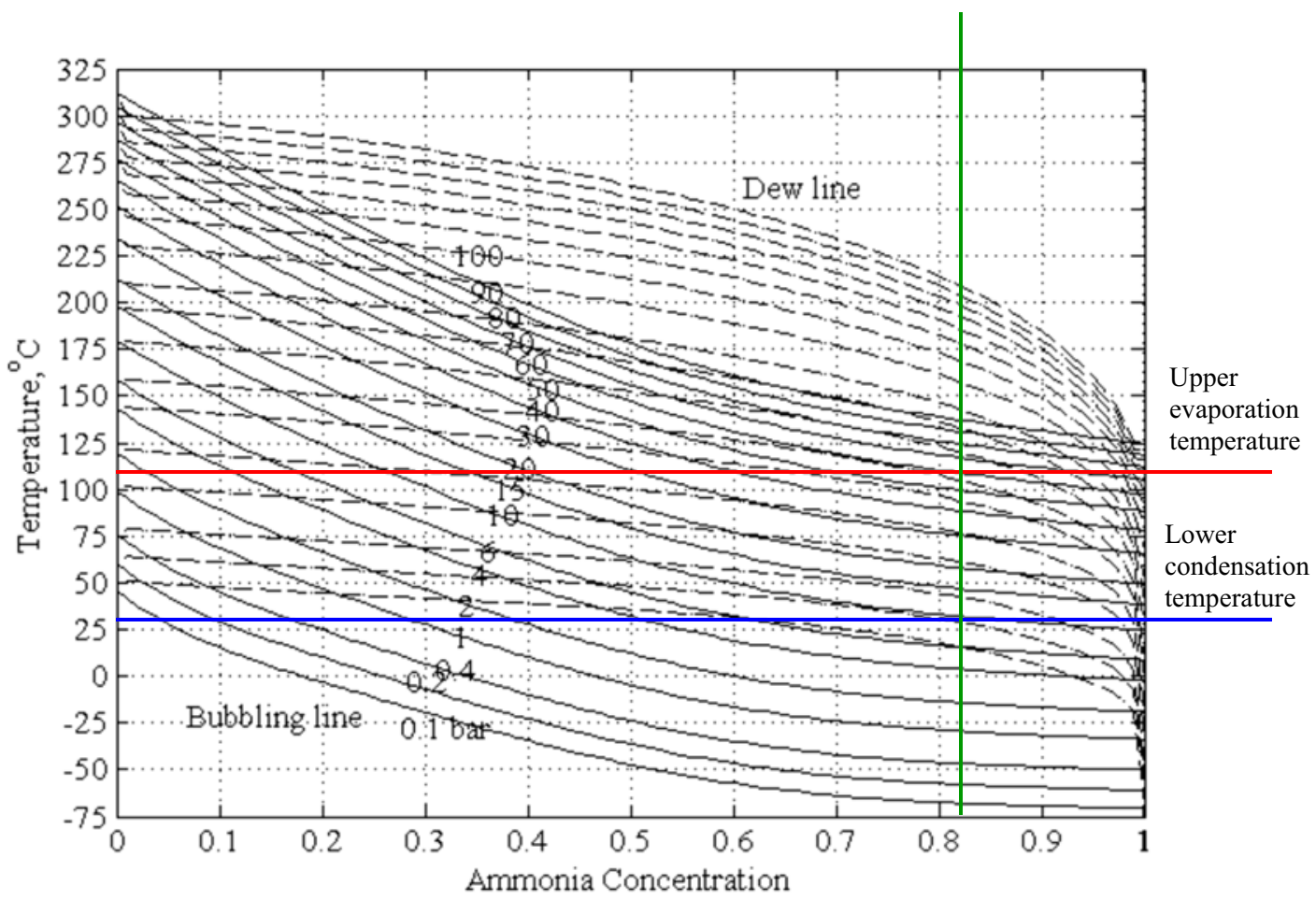

Fig. 3. Temperature-concentration diagram of ammonia-water mixture at different pressures (adapted from [22]).

The CHP plant performance was determined by simulation for summer and winter working conditions. In summer the district heat demand is lower and the cooling water temperature is higher $\left(22^{\circ} \mathrm{C}\right)$ while in winter the district heating heat demand is higher and the cooling water temperature is lower $\left(5^{\circ} \mathrm{C}\right)$. The main input parameters for simulation are given in Table 1.

Table 1. KCS-34 Kalina cycle based CHP plant input data (specifications and conditions)

\begin{tabular}{|c|c|}
\hline Parameter & Value \\
\hline Temperature of hot brine & $120^{\circ} \mathrm{C}$ \\
\hline Temperature of cold brine & $70^{\circ} \mathrm{C}$ \\
\hline Mass flow rate of brine & $92 \mathrm{~kg} / \mathrm{s}$ \\
\hline Cooling water inlet temperature & $\begin{array}{c}22^{\circ} \mathrm{C} \text { (summer) } \\
5^{\circ} \mathrm{C} \text { (winter) }\end{array}$ \\
\hline Evaporator pressure output & 35 bar \\
\hline Pinch point in evaporator, regenerators and heat exchanger & $5^{\circ} \mathrm{C}$ \\
\hline Pinch point in condensator & $10^{\circ} \mathrm{C}$ \\
\hline Pressure drop in evaporator, regenerators, condenser and heat exchanger & 1 bar \\
\hline Turbine isentropic efficiency & 0.87 \\
\hline Pump isentropic efficiency & 0.85 \\
\hline Mechanical efficiency of the pumps and turbine & 0.98 \\
\hline Generator efficiency & 0.96 \\
\hline
\end{tabular}

\section{Results and discussion}

The simulation results of KCS34 Kalina cycle based CHP plant for winter conditions are given in Fig. 3 and for summer conditions are given in Fig. 4. The Cycle Tempo software calculates the power generation and consumption, mass flow rate, temperature and pressure for each system component.

The net electrical power output is $1521.54 \mathrm{kWe}$ in winter and $2586 \mathrm{kWe}$ in summer. The heat supplied to district heating system is $9662 \mathrm{~kW}$ in winter and $3863 \mathrm{~kW}$ in summer. By using the heat and power cogeneration the energy efficiency is increased from $16.76 \%$ to $57.86 \%$ in winter and to $33.44 \%$ in summer. The energy efficiency is higher in winter because more of the heat from the geothermal water is used to heat the water in the district heating system. 


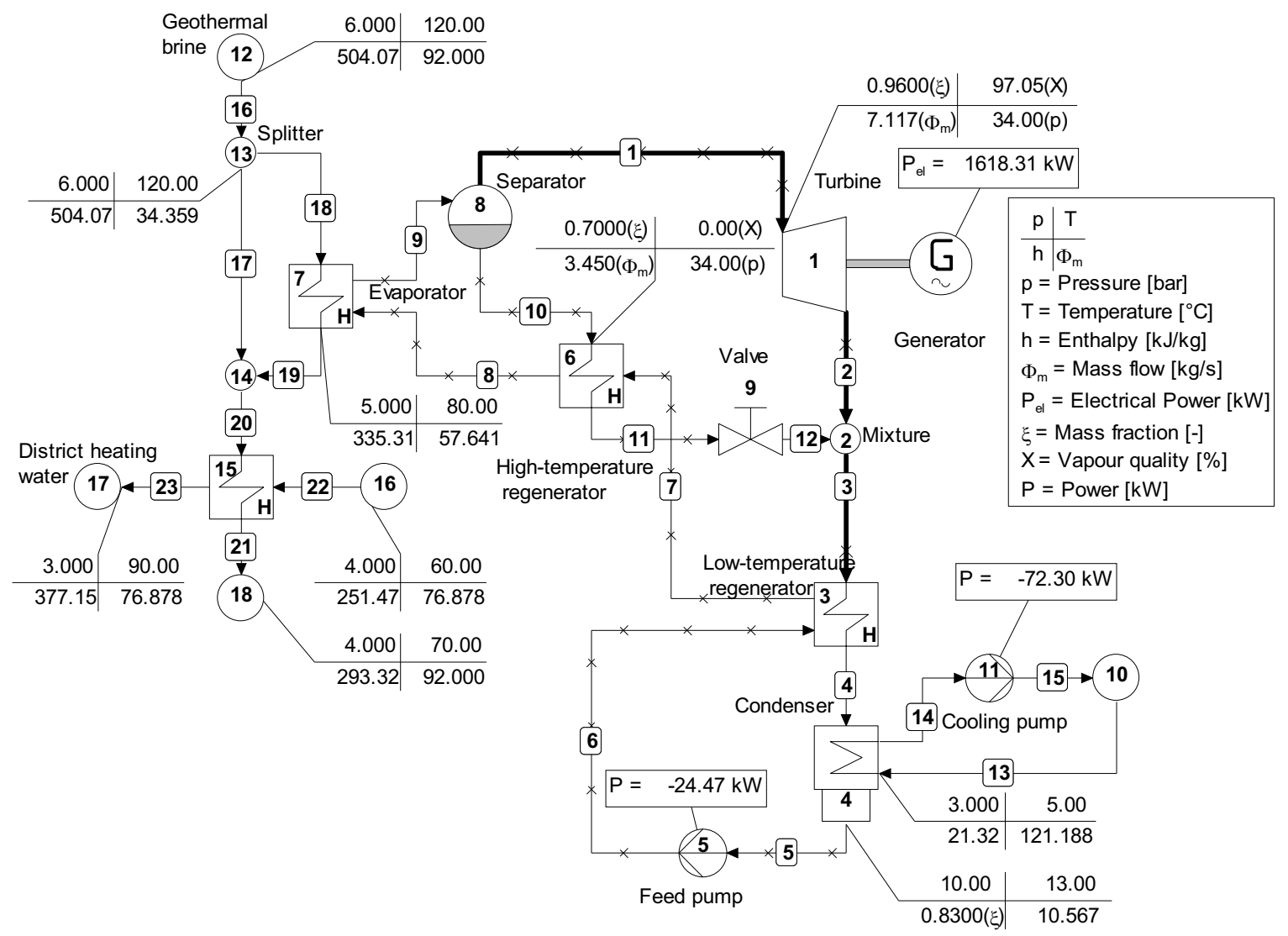

Fig. 3. Simulation results of the KCS-34 Kalina Cycle based CHP plant for winter conditions.

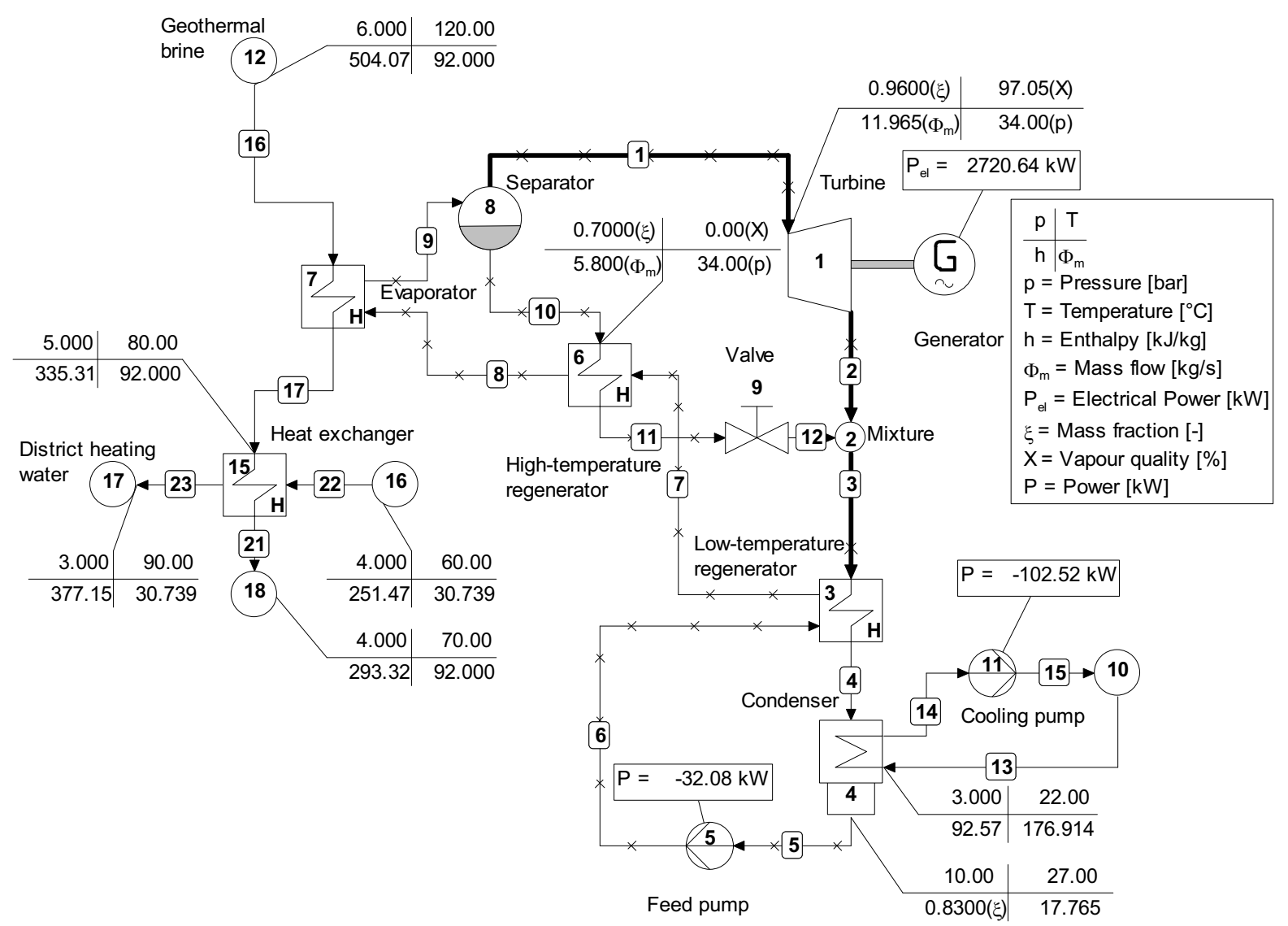

Fig. 4. Simulation results of the KCS-34 Kalina Cycle based CHP plant for summer conditions. 


\section{Conclusions}

To exploit the geothermal sources from the Bors reservoir (Romania) with temperature of $120^{\circ} \mathrm{C}$ for power and heat generation, a KCS-34 Kalina Cycle based system was configured. As the heating demand varies significantly all over the year a series-parallel combination of KCS-34 Kalina cycle system with district heating system was chosen. The geothermal brine heats the working fluid (ammonia-water solution) of the KCS-34 Kalina cycle and the water in district heating system from $60^{\circ} \mathrm{C}$ to $90^{\circ} \mathrm{C}$. The temperature of cold brine is $70^{\circ} \mathrm{C}$. The thermodynamic analysis was performed by using the Cycle-Tempo software package from ASIMPTOTE. After many simulations it was found the optimum ammonia concentration of 0.83 and optimum turbine exit pressure of 10 bars. The energy efficiency of the simple KCS34 Kalina Cycle of $16.76 \%$ can be increased, by using the heat and power cogeneration, to $57.86 \%$ in winter and to $33.44 \%$ in summer.

\section{References}

1. http://www.geothermaleranet.is/about-geothermal-era-net/geothermal-energy-/

2. R. Dipippo, Geothermal power plants: principles, applications, case studies and environmental impact (Elsevier, 2008)

3. O. Arslan, Energy 36 (2011)

4. R. C. E. Campos, P.J.C. Escobar, O.J. Venturini, L.E.E Silva, V.M. Cobas, D.M. Santos, et al., Appl Therm Eng 52 (2013)

5. R. DiPippo, Geothermics 33 (2004)

6. E. Wang, Z. Yu, Applied Energy 180 (2016)

7. H. A. Mlcak, TrGRC 26 (2002)

8. Q. Liu, A. Shen, Y. Duan, Appl Energy 148 (2015)

9. M. Astolfi, M.C. Romano, P. Bombarda, E. Macchi, Energy 66 (2014)

10. U. R Nasruddin, M. Rifaldi, A. Noor, J Mech Sci Technol 23 (2009)

11. S. Van Erdeweghe, J. Van Bael, B. Laenen, W. D'haeseleer 111 (2017)

12. S. Eyerer, F. Dawo, C. Wieland, H. Spliethoff $205(2020)$

13. S. Ogriseck, Applied Thermal Engineering 29, (14-15) (2009)

14. S. van Erdeweghe, J. van Bael, B. Laenen, W. D'haeseleer, Energy 150 (2018)

15. Z. Yu, J. Han, H. Liu, H. Zhao, Appl Energy 122 (2014)

16. V. Zare, Energy Convers Manag 105, (Supplement C) (2015)

17. D. Chandrasekharam, J. Bundschuh, Low-Enthalpy Geothermal Resources for Power Generation (CRC Press, 2008)

18. C. Karytsas, E. Kontoleontos, D. Mendrinos, Project LOW-BIN "Efficient Low Temperature Geothermal Binary Power", Proceedings European Geothermal Congress, Unterhaching, Germany, 30 May -1 June (2007)

19. C. Antal, Renewable energies. Geothermal energy (in Romanian) (University of Oradea 2017) http://geothermal.ro/pdf/Energii_regenerabile_Geotermal.pdf

20. M. Rosca, M. Antics, Current status of geothermal energy utilization in Romania, International Geothermal Days, Poland, Zakopane, September 13-17 (2004)

21. K. Deepak, A.V.S.S.K.S. Gupta, Int J Therm Technol 4 (2), (2014)

22. N. S. Ganesh, Thermodynamic optimization of Kalina cycle systems at low, medium and high temperature heat recoveries, PhD Thesis, VIT University (2014) 